\title{
First records of three species of Oxycraspedus Kuschel (Coleoptera: Belidae) in Argentina and use of a predictive model to compare their potential distribution with the range of their host-plant, Araucaria araucana
}

\author{
Primera cita de las tres especies de Oxycraspedus Kuschel (Coleoptera: Belidae) \\ en Argentina y uso de un modelo predictivo para comparar su distribución potencial \\ con el rango de su planta huésped, la Araucaria araucana
}

\author{
M.S. FERRER*, A.E. MARVALDI \& M.F. TOGNELLI
}
CONICET, Instituto Argentino de Investigaciones de Zonas Áridas, Entomología, CC 507, 5500 Mendoza, Argentina;
*e-mail for correspondence: msferrer@lab.cricyt.edu.ar

\begin{abstract}
The first records of the three known species of Oxycraspedus Kuschel (Belidae: Oxycoryninae) in Argentina are reported, and added to their known distribution in Chile. These weevils are of interest because of their association with the pehuén or monkey puzzle tree, Araucaria araucana, a species of conservation concern. Their distribution data are of value for the protection of biodiversity in natural areas of Patagonia. The potential distribution of Oxycraspedus, as predicted by a model using bioclimatic variables, is coincident as expected, with the geographic range of the araucaria host-plant.
\end{abstract}

Key words: Oxycoryninae, Araucaria araucana, bioclimatic variables, distribution models.

\section{RESUMEN}

Se reportan por primera vez en Argentina las tres especies de Oxycraspedus Kuschel (Belidae: Oxycoryninae) y se añaden a su distribución en Chile. Estos gorgojos son de interés debido a su asociación con el pehuén Araucaria araucana, una especie de gran interés en temas de conservación. Los datos sobre su distribución son valiosos para proteger la biodiversidad en áreas de la Patagonia. La distribución potencial de Oxycraspedus predicha por un modelo a partir de variables bioclimáticas, es coincidente, como se esperaba, con el rango geográfico de su planta huésped, la araucaria.

Palabras clave: Oxycoryninae, Araucaria araucana, variables bioclimáticas, modelos de distribución.

\section{INTRODUCTION}

The genus Oxycraspedus Kuschel (Coleoptera: Belidae: Oxycoryninae) has three described species, which were, so far, only known from Chile (Kuschel 1959, 1995, 2001, Marvaldi 2005).

The three species are associated with the conifer Araucaria araucana (Molina, 1782) C. Koch, being their adults and larvae found in decayed female cones of this plant (Kuschel 2001, Marvaldi et al. 2003 ${ }^{1}$ ). According to

1 MARVALDI AE, D LANFRANCO \& C RUIZ (2003) Hallazgo de larvas de Oxycraspedus (Coleoptera: Belidae: Oxycorynini) en estróbilos femeninos de Araucaria araucana (Mol.) Koch. XXV Congreso Nacional de Entomología, Universidad de Talca, Talca, Chile. p. 8. recent phylogenetic studies, the New World oxycorynines form a monophyletic tribe Oxycorynini, with Oxycraspedus retaining the ancestral belid association with conifers and being the sister group of the remaining Oxycorynini (Marvaldi et al. 2006). These weevils are considered to be survivors from Mesozoic times (Kuschel 1959, Farrel 1998, Marvaldi et al. 2002), thus antedating the Andes mountains uplift in the Cenozoic (Uliana \& Biddle 1998). Their specific association with the conifer Araucaria is also thought to be very ancient, probably ancestral for the group (Marvaldi et al. 2006).

Araucaria araucana, commonly known as "pehuén" or Monkey-Puzzle tree, is an 
evergreen conifer endemic to the Valdivian forests of Chile and Argentina. The actual distribution range covers from 37 to $40^{\circ} \mathrm{S}$, at both sides of Los Andes mountains in Chile and Argentina, and also a small area in Nahuelbuta mountains in Chile (Newton et al. 2003, Fig. 1). Although this tree species has been classified as vulnerable by the International Union for the Conservation of Nature (IUCN) and is listed on Appendix 1 of the Convention on International Trade in Endangered Species (CITES), there is still pressure from different land uses (Newton et al. 2003). This conifer hosts an amazing diversity of beetles (Mecke et al. 2005), being many of them weevils of the superfamily Curculionoidea (Morrone 1998, Kuschel 2001). A great proportion of the araucaria associated weevils has already been found at both sides of the Andes mountains in Argentina and Chile (Elgueta \& Marvaldi 2006 and references therein) such as: Mecomacer collaris (Voss, 1952), M. scambus Kuschel, 1954, Rhynchitomacerinus kuscheli (Voss, 1952) (Nemonychidae: Rhynorhynchinae); Eisingius araucariae Kuschel, 2001, Planus barbatus Kuschel, 1952, Calvertius tuberosus (Fairmaire \& Germain, 1860) (Curculionidae: Molytinae); Araucarius major, Kuschel, 1966 (Curculionidae: Cossoninae); Hylurgonotus tuberculatus (Eggers, 1942) (Curculionidae: Scolytinae). All known distribution records for Oxycraspedus are from Chilean localities, where pehuén occurs. Due to this close association with pehuén, it would have been expected to find these weevils also in the Argentine araucaria forests, however, no records of Oxycraspedus had been reported so far outside Chile. The goal of testing the hypothesis that the distribution of the weevil would coincide with that of the host-plant, which occurs at both sides of the Andean barrier, prompted the search of Oxycraspedus in decayed female cones from Argentine trees. Consequently, one of us (MSF) conducted a field expedition, in April 2006, to araucaria forests in Argentina to search for the presence of adults and immature specimens of Oxycraspedus. Additionally, we used a species distribution model (Guisan \& Thuillier 2005) to further test the congruence between the distribution ranges of Oxycraspedus and pehuén.

\section{MATERIAL AND METHODS}

The araucaria forests visited are located in the following localities of Neuquén province, Argentina: Primeros Pinos, Moquehue and Villa Pehuenia. The accession to them is from Zapala through the provincial route $\mathrm{N}^{\circ} 13$, and from the locality of Aluminé through the provincial route $\mathrm{N}^{\mathrm{o}} 23$.

Our target were dead female cones on ground, based on previous collecting experiences (Kuschel 2001, Marvaldi et al. 2003), but decayed female cones (without seeds) that were still on the trees, were also collected. Cones were placed in different bags grouped by locality. Male cones were collected as well, and kept separately from the female ones. They were both brought to the laboratory for close inspection. Larvae were killed in hot water and preserved in $80 \%$ ethanol. Most adult specimens were placed in $96 \%$ ethanol (for further molecular studies) and some were pinned and kept dried for morphological studies. Several cones were set aside and their larvae were reared until the adults emerged. The adult specimens were identified to species and sexed, following descriptions and keys provided by Kuschel (1959, 1995, 2001). All adult and immature weevils found are deposited in the Entomology collection of the Instituto Argentino de Investigaciones de Zonas Aridas (IADIZA).

\section{Predictive models of species distribution}

Species distribution models are used to predict species potential distribution by relating known species collection localities to a set of environmental variables that, presumably, reflect the ecological niche of the species (Guisan \& Thuillier 2005). They produce spatial predictions of habitat suitability indicating where the target species might occur. The modeled niches can be projected under different environmental scenarios, thus producing habitat suitability maps for past or future climatic conditions (Graham et al. 2004). Accordingly, we georeferenced and mapped the presently known localities of the three species of Oxycraspedus and used them to model their distribution utilizing predictive methods based on bioclimatic variables. Information about localities where Oxycraspedus is distributed in 


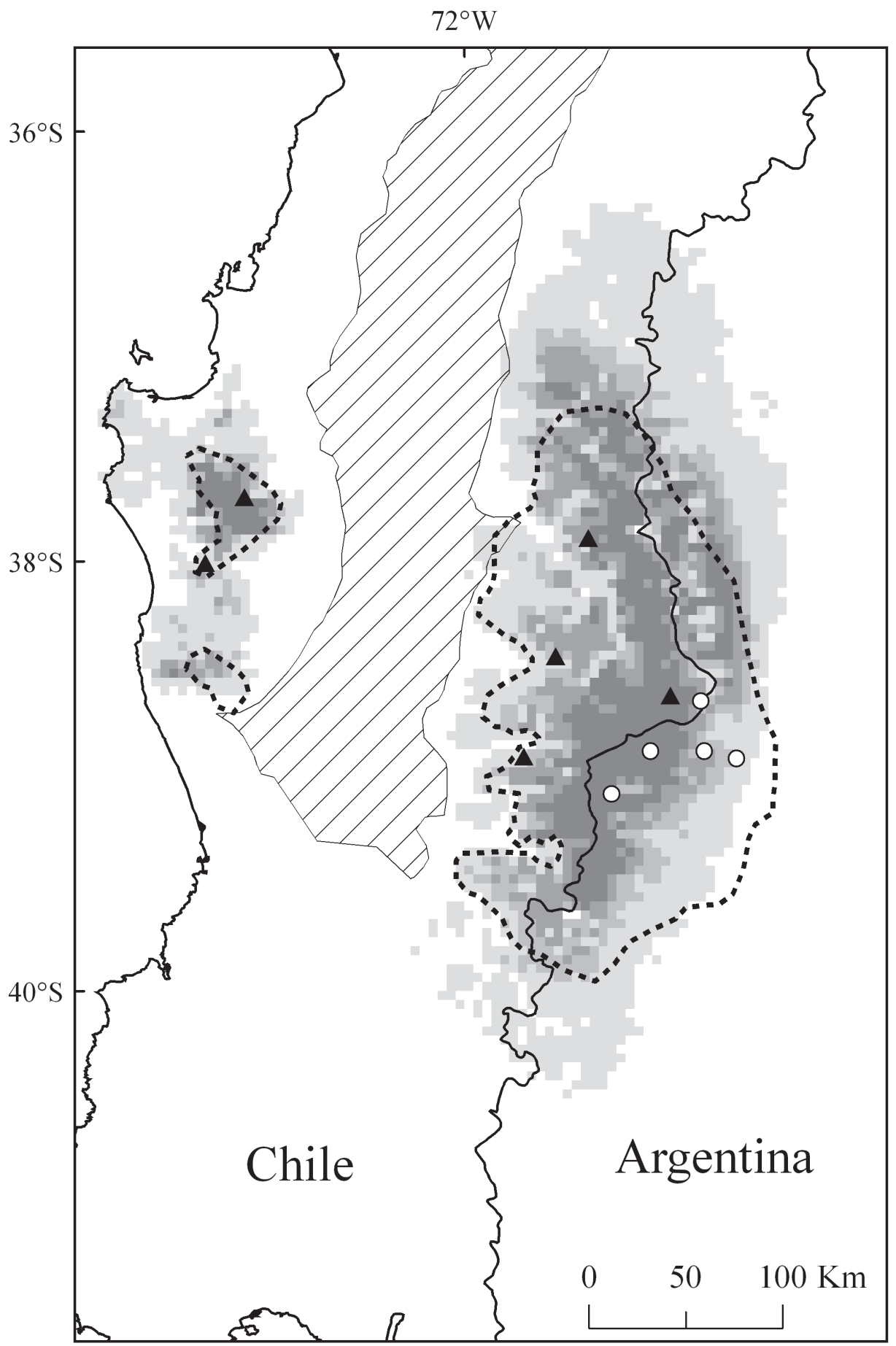

Fig. 1: Distribution of Oxycraspedus spp. in Chile and Argentina: published records (black triangles), new records (white circles). Potential distribution of the genus in shades of gray, with darker colors indicating higher probability of occurrence. Dotted line shows the approximate geographical distribution range of the host plant Araucaria araucana. Area with diagonal lines represents the Chilean Matorral ecoregion.

Distribución de Oxycraspedus spp. en Chile y Argentina: registros publicados (triángulos negros), nuevos registros (círculos blancos). La distribución potencial del género se muestra en escala de grises, con los colores más oscuros indicando una probabilidad de ocurrencia más alta. La línea de puntos muestra el rango de distribución geográfica aproximado de la planta huésped Araucaria araucana. El área con líneas diagonales representa la ecorregión del matorral chileno. 
Chile was taken from the literature and labels of the material deposited in the entomological collection of IADIZA. We used the program MaxEnt (Phillips et al. 2006), combined with 19 bioclimatic variables obtained from the WorldClim dataset (Hijmans et al. 2005) to model the distribution of Oxycraspedus. The resolution of the environmental layers used was, approximately, 4.6 x $4.6 \mathrm{~km}$. The distribution range of Araucaria araucana was reconstructed from the data provided by Echeverría et al. (2004).

\section{RESULTS AND DISCUSSION}

Geographical distribution of Oxycraspedus (see Fig. 1)

Oxycraspedus cribricollis (Blanchard, 1851) (Fig. 2A).

New records: Argentina. Neuquén: Aluminé, Primeros Pinos, 25 April 2006, Coll. S. Ferrer, one 9 (IADIZA); Aluminé, Villa Pehuenia, 26 April 2006, Coll. S. Ferrer, three 9 (IADIZA). Previously known distribution: Chile. Malleco: Pino Hachado, cordillera de Lonquimay (Kuschel 1959). In the original description of the species, Blanchard (1851) mentions its occurrence in Chile, in the "provincias centrales", without a precise locality. Additional material examined: Malleco: Reserva Natural Malalcahuelo, Coll. Leg. C. Ruiz and D. Lanfranco, one $\$$ (IADIZA); IV. 2003, Coll. Leg . C. Ruiz and D. Lanfranco, two , two larvae, two pupae (IADIZA); 17/18 July 2003, Coll. Leg. C. Ruiz and D. Lanfranco, two larvae (IADIZA).

Oxycraspedus cornutus Kuschel, 1959 (Fig. 2C and $D$ ).

New records: Argentina. Neuquén: Aluminé, Primeros Pinos, 25 April 2006, Coll. S. Ferrer, two $\sigma^{\prime \prime}$ and four $\$$ (IADIZA); Aluminé, Moquehue, 26 April 2006, Coll. S. Ferrer, two 우 (IADIZA); Aluminé, Villa Pehuenia, 26 April 2006, Coll. S. Ferrer, $23 \sigma^{\prime \prime}$ and 31 (IADIZA).

Previously known distribution: Chile. Arauco: Cordillera de Nahuelbuta (Kuschel 1959); Pichinahuel (Kuschel 1959). Bio-Bio: Volcán Callaquén (Kuschel 1959). Additional material examined: Malleco: Reserva Natural Malalcahuelo, 13 October 1999, Coll. Leg. C. Ruiz and D. Lanfranco, one $\sigma^{\prime \prime}$ and three $q$ (IADIZA).

Oxycraspedus minutus (Philippi \& Philippi, 1864) (Fig. 2B).

New records: Argentina. Neuquén: Aluminé, Primeros Pinos, 25 April 2006, Coll. S. Ferrer, two 9 (IADIZA); Aluminé, Moquehue, 26 April 2006, Coll. S. Ferrer, one $\sigma^{\prime \prime}$ (IADIZA); Aluminé, Villa Pehuenia, 07 February 2006, Coll. S. Ferrer, one 오 (IADIZA). Previously known distribution: Chile. Arauco: Pichinahuel, Cordillera de Nahuelbuta (Kuschel 1959). BioBio: Volcán Callaquén (Kuschel 1959). Malleco: Liucura (Kuschel 1959). The type locality ("prov. Santiago") provided in Philippi and Philippi (1864) is considered certainly erroneous by Kuschel (1959: 287). Additional material examined: Malleco: Reserva Natural Malalcahuelo, 13 October 1999, Coll. Leg. C. Ruiz and D. Lanfranco, one $\sigma^{\prime \prime}$ and one 9 (IADIZA), 24 January 2000, Coll. Leg. C. Ruiz and D. Lanfranco, three $\$$ (IADIZA).

\section{Biological notes}

Adult specimens were found hidden between the bracts or sporophylls at the base of female strobili. They feed on the parenchimatous tissues of the bracts, and on the cone axis (pith). Larvae of different sizes (probably different instars and species) were feeding inside the cone axis and at the base of the sporophylls. A few adult individuals were also collected on male cones, but this seems to be fortuitous. Oxycraspedus larvae were found exclusively in female strobili. This contrasts with male araucaria cones which nurse larvae belonging to several species of different beetles (Kuschel \& May 1990, 1996, Kuschel 2001, Mecke et al. 2005).

Potential distribution of Oxycraspedus and comparison with the distribution range of the host-plant

Given the host fidelity of the species of Oxycraspedus with A. araucana, it is clear that their distribution data are of value for the protection of biodiversity in natural areas of Patagonia. The potential distribution area for 
(A)

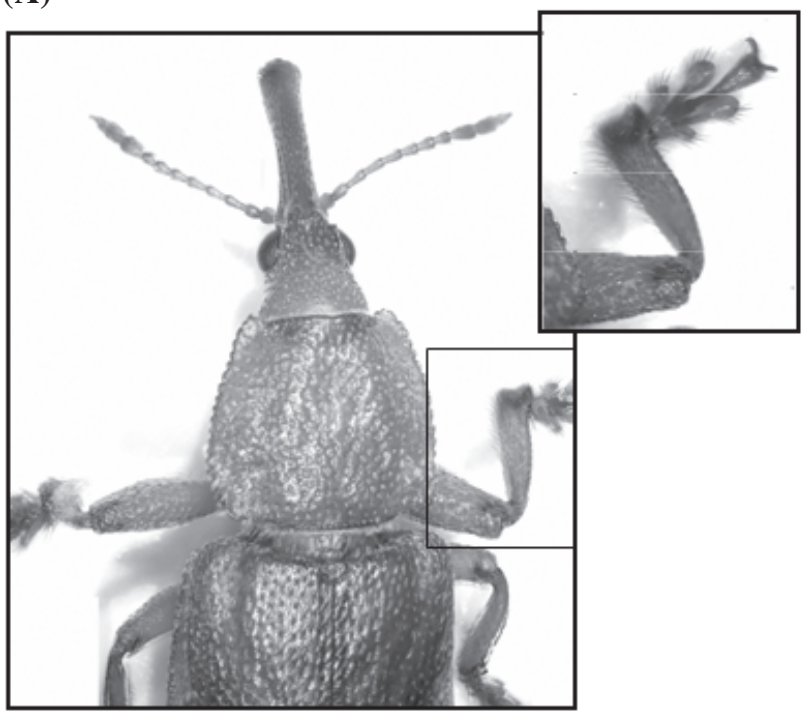

(C)

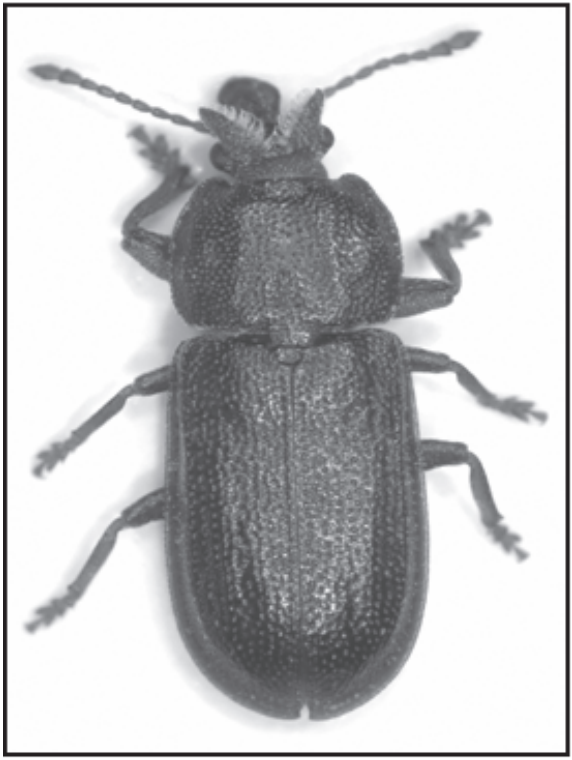

(B)

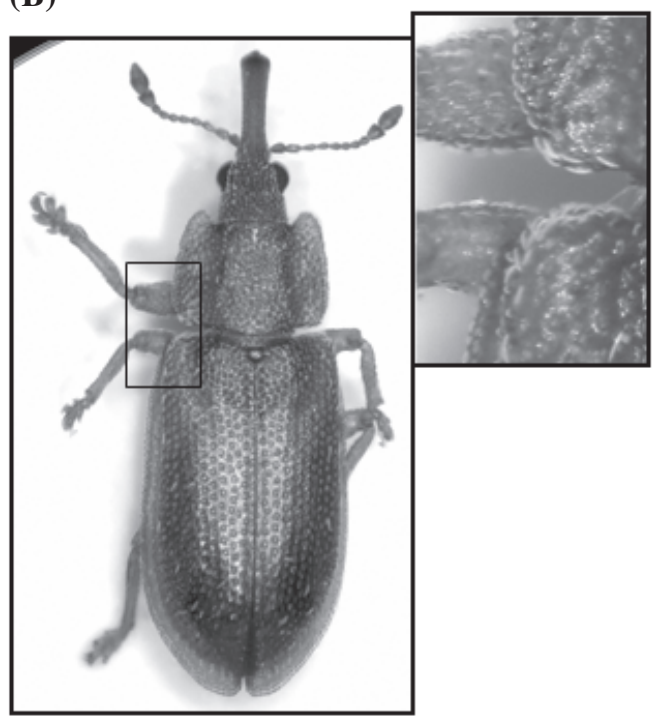

(D)

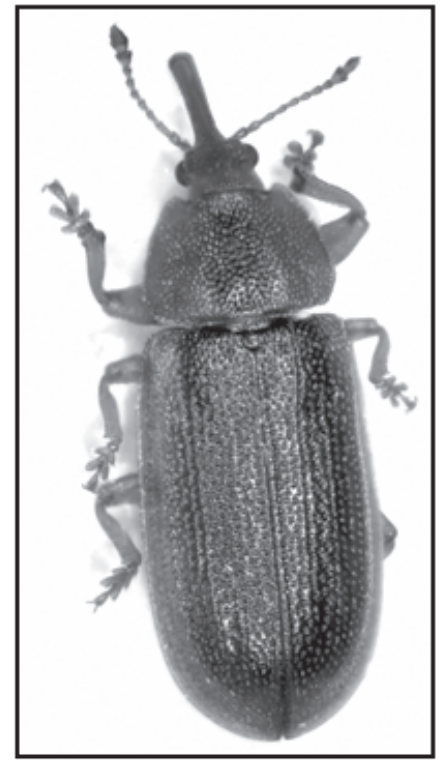

Fig. 2: Dorsal habitus of Oxycraspedus spp. (A) O.cribricollis, female, head and pronotum (protibia magnified showing the fringe of long setae along its inferior margin, diagnostic for this species); (B) O. minutus, female (humeral and pronotal areas magnified showing white elongated scales, diagnostic for this species); (C) O.cornutus, male (note the horn like projections on either side of frons, diagnostic of males of this species); (D) O. cornutus, female (note that its frons lacks horn like projections).

Hábito dorsal de Oxycraspedus spp. (A) O. cribricollis, hembra, cabeza y pronoto (protibia aumentada mostrando hilera de largas setas en su margen inferior, diagnóstica de la especie); (B) O. minutus, hembra (áreas humeral y pronotal amplificadas mostrando setas escamiformes blancas, diagnósticas de la especie); (C) O. cornutus, macho (notar las proyecciones corniformes a cada lado de la frente, diagnósticas del sexo masculino de la especie); (D) O. cornutus, hembra (notar la ausencia de dichas proyecciones frontales). 
Oxycraspedus predicted by the model is clearly coincident with the range of the araucaria hostplant (Fig. 1). The disjunct distributions of both the weevils and pehuén lie within the Valdivian Forest ecoregion, and are separated by the Chilean Matorral ecoregion (Fig. 1). Thus, the Chilean Matorral may act as an ecological barrier that isolates the populations of pehuén and, in turn, of Oxycraspedus spp. in Nahuelbuta (western Chile). In the same way, the Andes mountains represent a geographical barrier between Chilean and Argentine populations. The Oxycraspedus-araucaria association is supposed to date back to the Mesozoic and, therefore, much older than the Andes uplift in the Cenozoic. Those barriers had apparently not led to divergence into different weevil species on each side, although genetic differences might be expected between the different isolated populations of Oxycraspedus. However, a study by Bekessy et al. (2002) to evaluate the genetic variation of different populations of Araucaria araucana, showed that there is less than $2 \%$ of variability between the populations of the Coastal Range (Nahuelbuta), the argentine Andes and the chilean Andes regions. Further phylogeographic studies of Oxycraspedus species may contribute to explore genetic differences between populations of these weevils. Indeed, results of such studies may be conducive to conservation efforts, particularly if genetic differences do exist between the isolated populations, and are lacking protection.

\section{CONCLUSIONS}

The finding of Oxycraspedus individuals on araucaria forests on the Argentine side of the Andes confirms the hypothesis that the distribution of this weevil genus coincides with that of the host-plant A. araucana. The use of predictive models of species distribution is of great value for extrapolating from known localities of occurrence to other areas where environmental conditions are suitable for the species. This may prove extremely useful to plan collecting expeditions to areas where a species has not yet been recorded. Because of the presence of ecological and geographical barriers (Chilean Matorral and Andes mountains, respectively), genetic differentiation might occur among the populations of Oxycraspedus spp.

\section{ACKNOWLEDGEMENTS}

We thank Federico C. Ocampo and Sergio A. Roig for their support to conduct the field trip, and also to Eider R. Manzanos and Juan Antunez for their help during collecting activities. We are grateful to the "Dirección General de Bosques Provinciales", Neuquén province, Argentina, for the collecting permits and assistance. We also thank Dr. A. Townsend Peterson and two anonimous reviewers for their comments on the manuscript. A doctoral fellowship was awarded to MSF by the Consejo Nacional de Investigaciones Científicas y Técnicas (CONICET, Agentina). Additional financial support came from a CONICET grant (PIP $\mathrm{N}^{\circ}$ 5766), and from Fundación BBVA through "Yámana" project.

\section{LITERATURE CITED}

BEKESSY SA, TR ALLNUTT, AC PREMOLI, A LARA, RA ENNOS, MA BURGMAN, M CORTÉS \& AC NEWTON (2002) Genetic variation in the vulnerable and endemic Monkey Puzzle Tree, detected using RAPDs. Heredity 88: 243-249.

BLANCHARD E (1851) Insectos coleópteros: Tetramerés. Trímeros. In: Gay C (ed) Historia física y política de Chile: Zoología 5: 285-564. Maulde \& Renou, Paris, France.

ECHEVERRÍA C, C ZAMORANO \& M CORTÉS (2004) Conservation and restoration of Monkey Puzzle (Araucaria araucana) forests in Chile. Unpublished report. Available from: www.globaltrees.org/ downloads/ChileReportS.pdf (Accessed 3 July 2006).

ELGUETA M \& AE MARVALDI (2006) Lista sistemática de las especies de Curculionoidea (Insecta: Coleoptera) presentes en Chile, con su sinonimia. Boletín del Museo Nacional de Historia Natural 55: 113-154.

FARREL BD (1998) "Inordinate fondness" explained: why are there so many beetles? Science 281: 555-559.

GRAHAM CH, SR RON, JC SANTOS, CJ SCHNEIDER \& C MORITZ (2004) Integrating phylogenetics and environmental niche models to explore speciation mechanisms in dendrobatid frogs. Evolution 58: 1781-1793.

GUISAN A \& W THUILLIER (2005) Predicting species distribution: offering more than simple habitat models. Ecology Letters 8: 993-1009.

HIJMANS RJ, SE CAMERON, JL PARRA, PG JONES \& A JARVIS (2005) Very high resolution interpolated climate surfaces for global land areas. International Journal of Climatology 25: 1965-1978.

KUSCHEL G (1959) Nemonychidae, Belidae y Oxycorynidae de la fauna chilena, con algunas consideraciones biogeográficas. Investigaciones Zoológicas Chilenas 5: 229-271.

KUSCHEL G (1995) A phylogenetic classification of Curculionoidea to families and subfamilies. Memoirs of the Entomological Society of Washington 14: 5-33 
KUSCHEL G (2001) La fauna curculiónica (Coleoptera: Curculionoidea) de la Araucaria araucana. Revista Chilena de Entomología 27: 41-51.

KUSCHEL G \& B MAY (1990) Palophaginae, a new subfamily for leaf-beetles, feeding as adults and larva on Araucaria pollen in Australia. (Coleoptera: Megalopodidae). Invertebrate Taxonomy 3: 697719.

KUSCHEL G \& B MAY (1996) Discovery of Palophaginae (Coleoptera: Megalopodidae) on Araucaria araucana in Chile and Argentina. New Zealand Entomology 19: 1-13.

MARVALDI AE, AS SEQUEIRA, CW O'BRIEN \& BD FARRELL (2002) Molecular and morphological phylogeneticas of weevils (Coleoptera: Curculionoidea): do niche shifts accompany diversification? Systematic Biology 51: 761-785.

MARVALDI AE (2005) Larval morphology and biology of oxycorynine weevils and the higher phylogeny of Belidae (Coleoptera: Curculionoidea). Zoologica Scripta 34: 37-48.

MARVALDI AE, RG OBERPRIELER, CHC LYAL, T BRADBURY \& RS ANDRESON (2006) Phylogeny of the Oxycorininae sensu lato (Coleoptera: Belidae) and evolution of host plant associations. Invertebrate Systematics 20: 447-476.

Associate Editor: Eduardo Fuentes

Received August 18, 2006; accepted March 16, 2007
MECKE R, C MILLE \& W ENGELS (2005) Araucaria beetles worldwide: evolution and host adaptations of a multi-genus phytophagous guild of disjunct Gondwana derived biogeographic occurrence. Pró Araucária Online: 1: 1-18. www.pro-araucariaonline.com (Accessed 6 September 2005).

MORRONE JJ (1998) Weevils (Coleoptera: Curculionoidea) that feed on Araucaria araucana (Araucariaceae) in southern Chile and Argentina, with an annotated checklist. Folia Entomológica Mexicana 100: 1-14.

NEWTON A, S OLDFIELD, G FRAGOSO, P MATHEW, L MILES \& M EDWARDS (2003) Towards a Global Tree Conservation Atlas. UNEP-WCMC/ FFI. Available from: http://www.ourplanet.com/ wcmc/pdfs/trees.pdf (Accessed 3 July 2006).

PHILIPPI RA \& F PHILIPPI (1864) Beschreibung einiger neuen Chilenischen Käfer. (Schluss). Stettiner Entomologische Zeitung 25: 313-406.

PHILLIPS SJ, RP ANDERSON \& RE SCHAPIRE (2006) Maximum entropy modeling of species geographic distributions. Ecological Modeling 190: 231-259.

ULIANA MG \& KT BIDDLE (1998) Mesozoic-Cenozoic Paleogeographic and Geodynamic Evolution of Southern South America. Revista Brasileira de Geociências 18: 172-190. 
